\title{
DIGITAL GAME AS A NEW MEDIA AND USE OF DIGITAL GAME IN EDUCATION*
}

\author{
Deniz YENGIN \\ İstanbul Kültür University, Turkey \\ d.yengin@iku.edu.tr
}

\begin{abstract}
Transfer of information is trying to stay alive with the language but it is also supported and developed by the discovery of calligraphy. The development of technology in writing, keep records of information systematically. The discovery of electricity was opened in front of the electromagnetic discoveries and sharing of knowledge gained momentum over the channels. According to Huizinga game "game is an activity which is done voluntarily and in regular activities in a particular time and in space". This shows us the concept of the game is not "an unnecessary activity", it has turned into a sense of social and individual vital activity. Reproduced by the codes are real, users in different ways transmitted. Digital game is one of the ways of transmission. Digital media tools such as the game is played the video game and computer game. These environments are considered under the heading of Digital Games. Digital games provide an interactive environment with individuals as they allow electiveness, mobility and non-linearity. In an era of economic angst and where real and virtual identities are being disputed, individuals of the information society are searching for something different other than mass communication. They seek after individual experiences. Digital game environments allow users to gather ideas by allowing them to gain virtual experiences as opposed to real life events. Due to their rich visual content, digital games have the characteristic to shorten the learning period of individuals. Digital games offer users fantasy worlds where they can become lose themselves in different identities. This way through modeling, users are able to 'free' themselves. The main focus in this study will be to analyze the use of digital game in education. Alongside surveys, the study will also make use of literary sources. The universe of the study will be the Turkish students. The data collection method is conducting survey. The answers to the questions in the survey have been transferred to a SPSS environment, where descriptive and inferential analyses will lead us to understand the use of digital game in Turkey's education sector. The relationship between digital games and their users will also be examined. The quantitative study of education with digital games will be a useful source for future studies and will bridge the gap in this area.
\end{abstract}

Keywords: New media, game, digital game, digital education

\begin{abstract}
NEW MEDIA
Ünsal Oskay defines the communication as a "product of man's way of maintaining his existence and a phenomenon specific to man, undergoing changes relative with the developments in man's way of maintaining his existence" (Oskay, 1997: 7). Expressed as a phenomenon specific to man, the communication can be defined as the total sum of the social relationships undertaken by the human beings, which defines the nature of the man. The phenomenon of communication emerging from the needs of the man has developed over the time and entered our lives in various forms. Recently, we come across certain concepts such as information society, technological society and network society. Yoneji Masuda emphasizes the Information Society, while Manuel Castells underlines the Network Society. In today's communication environment where concepts
\end{abstract}

\footnotetext{
* Presented on International Conference on Education and New Learning Technologies, Barcelona, 2011.
} 
clash with one another, there is one common intersection. Digital media and users are the common point of this intersection.

The users define and save their identities virtually in this environment via the digital media. The users getting digitalized by 0 and 1 under the binary systems are constantly transforming. This transformation is also expressed as the "Byte Society". Thanks to the data exchange accelerated owing to the information technologies, the concept of "Global Village" mentioned by Marshall McLuhan is coming into reality. Prevalence of communication technologies, coupled with the Internet, facilitates the free movement of the information.

The new is not the opposite of the old. The new is built upon the foundation of the old. The new contains the old as well. The old is transformed into the new. The media designated as 'new' are recognized not as relative to the time, but by looking at such characteristics that are distinct from the old. That the new takes the concept of the old depends only on the technology which pertains to it. The new communication media being an extension of the digitality represent the media where the loss of data is prevented.

\begin{tabular}{|c|c|c|c|}
\hline $\begin{array}{c}\text { Roger Fidler } \\
\text { coevolution and } \\
\text { coexistence }\end{array}$ & $\begin{array}{c}\text { Lev Manovich } \\
\text { Rumerical } \\
\text { Representation }\end{array}$ & Martin Lister & Dennis McQuail \\
\hline Metamorphosis & Modularity & Interactivity & Socialization \\
\hline Propagation & Automation & Hypertext & Media Richness \\
\hline Sorvival & Varibility & Disporsal & Automation \\
\hline $\begin{array}{c}\text { Opportunity and } \\
\text { need }\end{array}$ & Transcoding & Virtuality & Hapiness \\
\hline Delayed adoption & & & Privacy \\
\hline & & & Individualization \\
\hline
\end{tabular}

Table 1: Principles of New Media

In this context, the communication environment is one of the basic fields where the human thought is shaped. This field is updated by means of the mass communication means which are shaped by the technological developments. Getting updated makes it necessary to attach the word of 'new' to it. The communication medium is added with and re-configured by the state of the art developments built upon it without losing its essence, evolving into a new communication process. In short, the new media consists of various communication areas distinct from one another, built upon the digital coding system, where communication occurs at high speeds.

\section{DEFINITION OF THE GAME}

The Game is an entertaining and arbitrary activity occurring outside the real world in general, which has its own specific rules and culture which are not definitive. The human beings have been developing methods of emulating the things they see around so far, giving birth to the concept of game. Huizinga defines the game as a "thing which does not exist actually but which fatally absorbs the players from top to toe while the freedom of working is going on outside consciously and while the "accustomed life", that is the existing life, is going on as it is." The game is an activity without an earning independent of any material benefit (Huizinga, 1950: 13). The game has its own time and space limits specific to itself, and it is an activity having certain rules and a methodical style unchanging within those limits. Jesper Juul defines the game as, " $A$ game is a rule-based system with a variable and quantifiable outcome, where different outcomes are assigned different values, the player exerts effort in order to influence the outcome, the player 
feels emotionally attached to the outcome, and the consequences of the activity are negotiable" (Juul, 2005: 36).

The traditional notion of game is today replaced by a notion of game which consists of the new communication mediums. At this juncture, the meaning of the 'new' here is very important. By saying that "When the new becomes old, it is sold by using notions such as newer, newest, brand new, most advanced, par excellence," İrfan Erdoğan and Korkmaz Alemdar emphasize the continuity of the traditional apprehension, expressing that the concept of new is transformed through some additions and maintain its continuity (Erdoğan \& Alemdar, 2005: 445). In sum, the game is a free action and consciously is outside the daily life, and though it is not regarded as a serious job, the player indulges in it intensively and wholly. No financial earning, profit or benefit is expected from the action (And, 2003). Its formation is within its own time and space boundaries, established rules and order.

\section{Concept of Digital Game}

As a new media, digital game is a remake of the reality created and transferred by coding of a reading system by means of a system of signs, added with sounds. The video console system, defined as the unity of the television and the console, drives the user to a distinct position. Digital games, offering an active role playing setting to the user, are directed by the user. Digital games contain various distinct messages.

In this paper, computer, video and mobile games having various distinct playing mediums are dealt with under the heading of digital game. The phenomenon of digital game is defined in accordance with the conventional notion of game and the digital games are classified. Digital games constitute a more complex integrity. User's integration occurs fast. There isn't any standard in the game. The games with a dynamic structure require from the user to learn the interfaces over and over again. Every new technology bears a trace of the previous one. Mul says that one thing that distinguishes the game from the fiction is that in a game the outcome is determined by the actions of the player, not by the author. The game is first of all interactive in that the player, the other players and the events affect one another collectively (De Mul, 2008: 93).

Digital games include the Atari games, the computer games, the console games, the mobile games and all distinct kinds (Binark \& Sütçü, 2009). In this sense, digital game is a personal media which contains the digitality, interactivity, virtuality, varibility, modularity features of the new media and incorporates such features into the act of game playing. Such mediums can also include and harbor such concepts and features which are characterized as old or conventional. As technological advances and broadly structured digital systems go on their way by generating new mediums day by day, the definition of digital game inevitably broadens day by day (Atabek, 2001). Comprising the characteristics of the notion of conventional game, the digital game has given birth to a new notion of game.

The traditional notion of game, which is based on physicality, is replaced with digitally produced game mediums (Çağıltay, 2010). The medium of game created by physical practices and tools is transformed into a medium based on a visual system with the participation of the users. This transformation process brings along new characteristics.

\section{METHODOLOGY}

In this study, video and computer games are dealt with under the heading of digital game, and the contents of the games are reviewed both in terms of quality and quantity. In addition to such interpretations, the data as regards to obtaining of information by the users from the digital games 
compiled from the questionnaires answered by the users are analyzed. The digital game is a medium which enables the users to derive idea through virtual experiences, rather than from real events. Owing to their rich visual content, the digital games have some characteristics that shorten the learning processes of the individuals (Prensky, 2001).

\section{FINDINGS}

In this study, the data have been gathered by the inquiry technique as the chosen methodology. The data have been compiled from the answers given by the students participating in the research to the questionnaires on the subject matter. In this research, 420 students have answered the questionnaire. The questionnaire consists of 13 closed-end questions. Of these questions, two are about the demographic characteristics of the students, one about whether they play digital games or not, and the remaining ten are questions about their views about whether the digital games contribute to the education of the individual. Especially an ordinal scale has been used for the questions concerning the views of the participants about the contribution of the digital games to the education of the individual.

By means of the questionnaires, data have been gathered from 420 students. Of the students who answered the questionnaires, $57 \%$ (238 students) are male and 43\% (182 students) female. (Table 2)

\begin{tabular}{|l|c|c|}
\hline & Frequency & Percentage \\
\hline Female & 182 & $\% 43$ \\
\hline Male & 238 & $\% 57$ \\
\hline Total & $\mathbf{4 2 0}$ & $\mathbf{\% 1 0 0}$ \\
\hline
\end{tabular}

Table 2: Distribution according to gender

The participants were asked questions distributed according to 4 age groups. Distribution is measured according to the age groups of 13-18, 19-24, 25-30 and 31-36. It has been found that the number of the participants in the age group of $19-24$ is higher than the rest with a rate of $82 \%$. Of the students who answered the questionnaire, 70\% (294 students) play digital games. Ten (10) questions prepared on Likert scale have been asked to 294 students. The five-level Likert scale has been used for the following items. Table 3 shows the distribution of the digital games in education. 


\begin{tabular}{|c|c|c|c|c|c|c|c|c|c|c|}
\hline & \multicolumn{2}{|c|}{$\begin{array}{l}\text { Strongly } \\
\text { Disagree }\end{array}$} & \multicolumn{2}{|c|}{ Disagree } & \multicolumn{2}{|c|}{$\begin{array}{l}\text { Neither } \\
\text { Agree nor } \\
\text { Disagree }\end{array}$} & \multicolumn{2}{|c|}{ Agree } & \multicolumn{2}{|c|}{$\begin{array}{l}\text { Strongly } \\
\text { Agree }\end{array}$} \\
\hline & $f$ & $\%$ & $f$ & $\%$ & $f$ & $\%$ & $f$ & $\%$ & $f$ & $\%$ \\
\hline $\begin{array}{l}\text { Playing digital game is an important spare } \\
\text { time occupation. }\end{array}$ & 5 & 1 & 10 & 2 & 15 & 2 & 130 & 30 & 280 & 66 \\
\hline Playing digital game is a loss of time. & 125 & 30 & 180 & 43 & 51 & 12 & 45 & 10 & 19 & 5 \\
\hline $\begin{array}{l}\text { Playing digital game arouses wonder for } \\
\text { learning. }\end{array}$ & 29 & 7 & 23 & 5 & 101 & 24 & 116 & 27 & 151 & 37 \\
\hline $\begin{array}{l}\text { Playing digital game aids development of } \\
\text { certain useful knowledge and skills. }\end{array}$ & 26 & 6 & 70 & 16 & 78 & 18 & 172 & 42 & 74 & 18 \\
\hline Digital games are fit for each age group. & 211 & 50 & 101 & 24 & 53 & 12 & 22 & 5 & 33 & 7 \\
\hline $\begin{array}{l}\text { Playing digital game with a group promotes } \\
\text { development of social skills of the individuals. }\end{array}$ & 7 & 1 & 23 & 5 & 45 & 11 & 114 & 27 & 231 & 56 \\
\hline $\begin{array}{l}\text { Digital games can be used in parallel with } \\
\text { the objectives of the teaching programs in } \\
\text { schools. }\end{array}$ & 24 & 6 & 93 & 22 & 180 & 43 & 85 & 20 & 38 & 9 \\
\hline $\begin{array}{l}\text { Digital games can be an efficient tool in learning } \\
\text { when used as an aid to teaching in the class. }\end{array}$ & 20 & 5 & 26 & 6 & 74 & 18 & 120 & 28 & 180 & 43 \\
\hline $\begin{array}{l}\text { Digital game can be an efficient tool in } \\
\text { learning when a target is assigned to the } \\
\text { player. }\end{array}$ & 6 & 1 & 56 & 14 & 147 & 35 & 90 & 21 & 121 & 29 \\
\hline $\begin{array}{l}\text { Digital games used in the class provide both } \\
\text { guidance and a complementary tool. }\end{array}$ & 12 & 2 & 34 & 8 & 96 & 24 & 165 & 39 & 113 & 27 \\
\hline
\end{tabular}

Table 3: Distribution of assessment on digital game in education

As a result of this study, which assesses the views of the students about the digital games in education, provides important data. The questionnaires answered by the students reveal that $70 \%$ of the students play digital games. Majority of the students who play digital games defend that the digital games should be used in parallel with the education in school and that if the students playing the digital games are assigned with a certain target, the digital games will be more efficient in learning. In this context, digital games should be made a part of the formal education, so that the courses will be more explanatory and understandable.

\section{CONCLUSION}

The game is a life laboratory. The game is a kind of vehicle by means of which the child conveys his/her sorrow, concerns, joy, etc. In the games, which make the connections between the imaginary world and the real world more sensible, the child becomes acquainted better with his/her surroundings, the life and himself/herself by filtering them through the game. With these characteristics, the games become an important communication medium. The best example that can be given to the new media today is the digital games. The digital games are popular personal communication means. A very different kind of games are offered to sale in shops and consumed by the users. Digital games are popular for a number of reasons. First of such reasons is that the individuals cannot attain the levels or have the attributes they desire. Seeking to satisfy their own particular desires, the individuals resort to digital games to find what they want in the real life. Digital games are preferred by the users as the new media means owing to the vast features they offer.

Majority of the students participating in this research are playing digital games. The students show interest in the use of digital games as part of the formal education. In this regard, visual presentations and examples by means of games in the class become important. Information transferred to the students by means of the digital games should be converted into actions through applications or practices. Owing to reinforcement of the transferred information by means of practical works make learning faster and more durable. This research shows that use of digital games in formal education is an important issue. The information passed on to the students is 
both learned faster and retained longer by them. Consequently, digital games should be used as an important communication medium with their characteristics which can direct their education life.

\section{REFERENCES}

And, Metin. (2003). Oyun ve Bügü: Türk Kültüründe Oyun Kavramı. İstanbul: Yapı Kredi Yayınlar1.

Atabek, Ümit. (2001). İletişim ve Teknoloji Yeni Olanaklar - Yeni Sorunlar. Ankara: Seçkin Yayınlar1.

Binark, Mutlu \& Bayraktutan-Sütçü, Günseli \& Fidaner, Işık Barış. (2009). Dijital Oyun Rehberi: Oyun Tasarımı, Türler ve Oyuncu. İstanbul: Kalkedon Yayınları.

Çağıltay, Kürşat ve Yılmaz, Erdal. History of Digital Games in Turkey http://www.digra.org/dl/db/06276.58368.pdf (05.02.2010)

De Mul, Jos. (2008). Siberuzayda Macera Dolu bir Yolculuk (Çev: Ali Özdamar). İstanbul: Kitap Yayınlar1. s.93.

Erdoğan, İrfan ve Alemdar, Korkmaz. (2005). Öteki Kuram: Kitle İletişim Kuram ve Araştırmalarının Tarihsel ve Eleştirel bir Değerlendirmesi. Ankara: Erk, s.445.

Huizinga, Johan. (1950). Homo Ludens: . Boston: Beacon Press, s.13.

Juul, Jesper. (2005). Half-Real: Video Games between Real Rules and Fictional Worlds. Cambridge: The MIT Press, s.36.

Oskay, Ünsal. (1997). İletişimin ABC'si. İstanbul: Der Yayınları, s.7.

Prensky, M. (2001) Digital Game-Based Learning. New York, NY: McGrawHill. 